\title{
Biological Treatment of Landfill Leachate Using Sea Water Microflora Under Aerobic and Anaerobic Conditions
}

\author{
Marzieh Ayati Najaf Abadi ${ }^{1}$, Giti Emtiazi ${ }^{2}$, Sara Saadatmand ${ }^{2}$, Morte za Barani ${ }^{3}$, Hossein Ghanavati ${ }^{4, *}$ \\ ${ }^{1}$ Department of science, Islamic Azad University, Tehran, Iran \\ ${ }^{2}$ Department of Biology, university of Isfahan, Isfahan, Iran \\ ${ }^{3}$ Analy tical laboratory of the Isfahan Composting Factory, Isfahan, Iran \\ ${ }^{4}$ Department of Biology, university of Isfahan, Isfahan, Iran
}

\begin{abstract}
The present study demonstrates an appropriate technique for treatment of landfill leachate. Pretreatment with alum and anionic poly electrolyte as coagulant and flocculent materials caused $43 \%$ reduction of COD. Sucrose and nutrient broth were used for enrichment of sea water microflora. The pretreated leachate was used for determination of aerobic and anaerobic biological treatments of sea water enriched microflora. BOD5, COD and TSS reduction were acquired in best samples $90.3 \%, 95.1 \%$ and $44.8 \%$ in aerobic and $31.2 \%, 38.3 \%$ and $37.3 \%$ in anaerobic conditions, respectively. The metal removal was determined in aerobic and anaerobic treatments and up to $90 \%$ metal removal acquired in some cases.
\end{abstract}

Keywords Sea Water Micro flora, Chemical and Biological Treatment, Landfill Leachate

\section{Introduction}

Leachate is one of the main environmental concerns associated with landfill management because it contains pollutions such as organic matter, heavy metals, and salts which have the potential to damage the quality environ ment and are the real damage after composting[1]. Leachate composition is unreliable and space at a particular landfill[2]. The composition of the leached waste water is based on the composition and the degree of contouring and compacting of compost, climates conditions at the landfill, local rainfall that regulates humidity level, temperature and landfill age. These conditions must be fixed and treated appropriately, to avoid contamination of receiving environment[3]. Treatment methods must be coordinated to the actual individuality of the exacting leachate [4]. To remove the majority of pollutants, biological methods used beside with physicochemical treatment[15]. Usually, only application of biological treatment is not an option due to the leachate distinctiveness [1]. In addition, neither biological nor physicochemical treatment alone achieves high treatment efficiencies significant for occurrence of high-molecular weight organics that are difficult to remove and inhibitory effects of organics, inorganic salts and metals for waste microorganis ms[1]. Among various biological technologies, it is smart to use mutual anaerobic and aerobic

* Corresponding author:

ghanavatih@hotmail.com (Hossein Ghanavati)

Published online at http://journal.sapub.org/ijbe

Copyright (C) 2012 Scientific \& Academic Publishing. All Rights Reserved systems for the removal of COD and ammonia, especially for the treatment of landfill leachate[5]. In predictable biological reactor, anoxic, anaerobic and aerobic conditions are separated in sequencing sets of reactors [6]. Up to now many biological treatments like, up-flow anaerobic; sludge blanket reactor[7, 8]; anaerobic sequencing batch reactor[8]; aerated lagoons and activated sludge[9] have been investigated for Leachate treatment. The kind of treatment should be based on characteristics of leachate.

Conductivity is used as an indicator of the abundance of dissolved inorganic species, chemicals or total concentration of ions like sodium, potassium and chloride in water. Conductivity is not a problem in itself and just because it is above certain level does not mean that the water will cause infection[16, 10]. However high salt in the leachate make it resistant to biodegradation.

In this research biological treatment of leachate by marine microorganism was investigated for first time. Also the objective was to evaluate the biological treatability of the leachate from municipal landfill sites by observing removal capacity of COD and organic pollutants. The heavy metals removals were also investigated.

\section{Materials and Methods}

\subsection{Sampling of Landfill Leachate}

Ten liters of leachate was directly taken from a 21-yr old landfill located in Gardane Zeinal in Isfahan-Iran. Leachate is collected by drainage pipes into the commercially and sandy lagoons, whereas no treatment process are performed. 
The analysis of this leachate was carried out and the results are given in Table 1 . The leachate was stored at $-40^{\circ} \mathrm{C}$ in the refrigerator to keep the composition as uniform as possible for future experiments.

\subsection{Analytical Methods}

\subsubsection{Coagulation and Flocculation}

Coagulation-flocculation experiments with jar test equipment, equipped with four beakers with different coagulants $\mathrm{Al}_{2} \quad\left(\mathrm{SO}_{4}\right)_{3}, \quad \mathrm{FeCl}_{3}, \quad \mathrm{FeSO}_{3}$ and anionic polyelectrolyte as flocculants (supplied from Merck) at various dosages on removing the COD of leachate were investigated. First, $\mathrm{pH}$ of samples were readjusted to desired $\mathrm{pH} 6.5$ (Metrohm 632) by addition of $1 \mathrm{~N} \mathrm{NaOH}$ and then the varying coagulant concentrations at room temperature $\left(20^{\circ} \mathrm{C}\right)$ were added into $1 \mathrm{~L}$ of the raw landfill leachate. The samples were treated by fast mixing for 3 minute $(120 \mathrm{rpm})$, slow mixing for $15 \mathrm{~min}$ (20rpm) and 1 hour's sedimentation with chemical coagulation, the final gravity settling stage lasted for another 24-48 h, and then the supernatant was analyzed for COD according to Standard Methods [17].

\subsection{Biodegradability Testing}

Biodegradability of the raw landfill leachate was determined by applying, enriched microorganisms from (high salt environments) sea water. We determined the biodegradability of the leachate by sea microflora, and to avoid any toxic material, pretreated leachate was used. The experiment included enrichment, incubation and investigation of treatment efficiency. The main items $\mathrm{pH}$, $\mathrm{BOD}_{5}$ (Biochemical Oxygen Demand), COD (Chemical Oxygen Demand), EC (electrical conductivity) were monitored using the standard methods recommended by US Environmental Protection Agency[17].

\subsubsection{En rich ment of Sea Water Microflora}

Different substances such as, sucrose (10 gl-1), nutrient broth (1gr per 100cc sea water), cellulose with yeast extract (0.5 grl-1 and 2 grl-1 respectively) were used for enrichment of sea water flora individually. Enrichment was performed in aerobic and anaerobic condition. Aerobic mediums were placed on $37^{\circ} \mathrm{C}$ shaker incubator at $200 \mathrm{rpm}$ for one week. Closed tap bottles were choose for anaerobic condition and mediums incubated 3 week at $37^{\circ} \mathrm{C}$ incubator. The suspensions were centrifuged after enrichment and the pellets were used as biomass.

\section{Results and Discussion}

\subsection{Characterization of the Landfill Leachate}

The characterization of raw leachate from Isfahan landfill is shown in table 1. It contains high concentrations of organic and inorganic material, thus released leachate may cause serious pollution to ground water aquifers as well as adjacent surface waters. the acidic $\mathrm{pH}$ might caused by plenty of volatile fatty acids like acetic acids, lactic acids and amino acids that exist in foods and fruits and also, the high partial pressure of $\mathrm{CO}_{2}$. High salt concentrations in the leachate are due to the great amount of foods waste, disposed in to the landfill. The main reasons for the presence of $\mathrm{Na}$ in the leachate are the wide use of $\mathrm{Na}$ salts in industry and domestic activity (paper, soap, etc)[18]. Potassium is released during refuse decomposition and the main source of $\mathrm{K}$ is plant material and discarded food, which is the main component of Iranian municipal solid waste. The presence of heavy metals in the leachate is due to industrial waste and household nonhazardous waste[19]. Heavy metals if not removed, could cause serious consequences to human beings and the environment. Heavy metals can accumulate in the biological tissues of the body and cause serious diseases such as neurotoxin effects, renal failure (lead), genetic anomalies and cancer risk (cadmium, arsenic). This indicates clearly that need for pretreatment of leachate prior to bio logical treat ment[11].

\begin{tabular}{ccc}
\multicolumn{2}{l}{ Table 1. Characteristics of Isfahan landfill leachate } \\
Parameter & Unit & Range \\
pH & & $5.5-6$ \\
Electrical & ds.cm-1 & $20000-50000$ \\
Conductivity & mg.l-1 & $1000-3400$ \\
TSS & mg.l-1 & $37000-41000$ \\
TDS & mg O2.l-1 & $37000-49000$ \\
BOD5 & mg O2.l-1 & $127000-176000$ \\
COD & mg.l-1 & $1-5$ \\
Lead & mg.l-1 & $1-2$ \\
Nickel & mg.l-1 & $0.1-1$ \\
Cadmium & mg.l-1 & $0.2-1$ \\
Chromium & mg.l-1 & $100-200$ \\
Iron & mg.l-1 & $20-50$ \\
Zink & mg.l-1 & $0.1-2$ \\
Copper & mg.l-1 & $10-25$ \\
Manganese & mg.l-1 & $1450-4100$ \\
Potassium & mg.l-1 & $1270-2450$ \\
Sodium & mg.l-1 & $1520-1950$ \\
Calcium & mg.l-1 & $320-590$ \\
Magnesium & mg.l-1 & $2000-4000$ \\
Sulfate & &
\end{tabular}

\subsection{Coagul ation and Flocculation}

The composition of the leached wastewater is based on the composition and the degree of contouring and compacting of solid wastes, physicochemical conditions at the landfill, local rainfall regime that regulates moisture level, geology and landfill age[3]. According to Table 1, we conclude that old leachate with a BOD5/COD ratio of 0.36 could be considered as relatively stabilized wastewater. Thus, using biological processes for further treatment of these wastes may be ineffective and other methods such as chemical coagulation could be applied. Although the coagulation/flocculation is relatively a simple technique, this treatment only allows to moderate removal of organic compounds. A few negative situations such as sludge generation and high aluminum concentration were revealed after this process. 
The leachate sample in this study was coagulated by different coagulant with anionic polyelectrolyte (Table 2). It should be noted that precipitation of alum by organic compounds in leachate is more than other coagulants. Treatment efficiency (Fig.1) according to COD, reached $43 \%$ at $1500 \mathrm{mg} .1-1$ of $\mathrm{Al}_{2} \quad\left(\mathrm{SO}_{4}\right)_{3}$ and anionic polyelectrolyte. Many reports related to chemical treatment of leachate are available. In an old landfill leachate by an initial COD of $2461 \mathrm{mg} .1-1$, reported that COD was removed $25 \%$ with $1000 \mathrm{mg} .1-1$ alum[12]. It was recognize that, low amount of flocculent (2.5 mg.1-1) have better treatment efficiency in removal of COD $(51 \%)$ than higher a mounts.

Table 2. Optimal amount of coagulation-flocculation for the leachate pretreatment

\begin{tabular}{cccc}
\hline Coagulant & $\begin{array}{c}\text { Amount of } \\
\text { Coagulant(mg.l-1) }\end{array}$ & Polyelectrolyte & $\begin{array}{c}\text { Amount of } \\
\text { Polyelectrolyte } \\
\text { (mg.l-1) }\end{array}$ \\
\hline Alum & 1500 & Anionic & 150 \\
$\begin{array}{c}\text { Ferrous } \\
\text { Sulfate }\end{array}$ & 2500 & Anionic & 250 \\
$\begin{array}{c}\text { Ferric } \\
\text { chloride }\end{array}$ & 2500 & Anionic & 250 \\
\hline
\end{tabular}

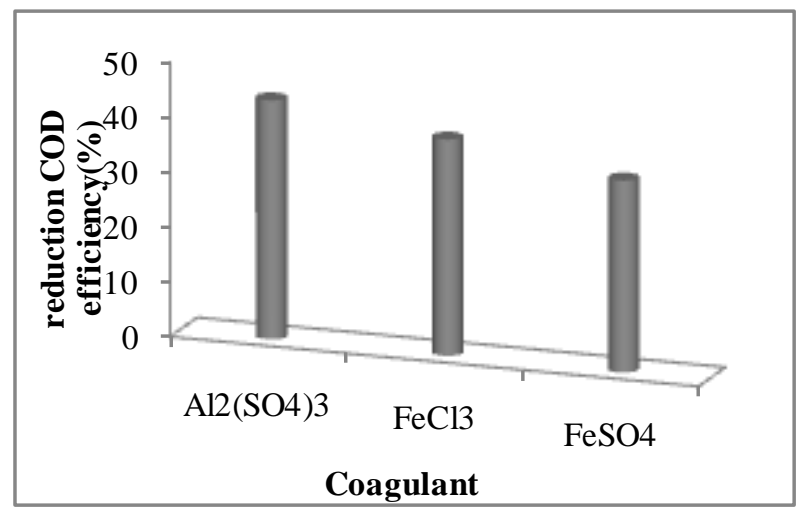

Figure 1. Leachate treatment efficiency according to COD with the various coagulants

\subsection{Biological Treatment by the Sea Microflora In Aerobic and Anaerobic Conditions}

During accomplished investigations in this project, sea microflora was used because of high concentration of salt and organic load of Isfahan landfill. Mic roorganisms are not able to grow well on this wastewater and biological treatment does not work perfectly. Whereas chemical qualities of leachate, such as Electrical Conductivity and concentration of high salt, is similar with chemical qualities of the sea water, it was recognizable that sea microflora could tolerate this special landfill wastewater and could reduced organic compounds. Therefore for the first time in this project, we used enriched sea water microflora. It was enriched in three materials, and after inoculation in the leachate, experiments accomplished.

Figure 2 shows the BOD and COD reduction efficiency in aerobic system. With the degradation of organics by enriched microflora in nutrient broth and sucrose, the BOD reduction in the system increased at the early stage, and reached maximum value of $90.3 \%$ on day 7 , then remained stable. Whereas cellulose enriched microflora doesn't represent enough effect on reduction of BOD and COD. Also the best reduction of TSS was showed in samples with addition of nutrient broth and sucrose (43.2 and $44.8 \%$ respectively).

The table 3 shows BOD, COD and TSS reduction of leachate after treatment with different enriched microflora in anaerobic conditions within 21 days.

The table 4 and 5 shows removal efficiency of metals in the treated leachate with nutrient broth and sucrose in aerobic and anaerobic conditions. There are significant effects on $\mathrm{Fe}, \mathrm{Cu}$, and $\mathrm{Mg}$ removal.

Melgie et.al (2010) for extracting heavy metals used 2 samples of sea water and Karoon's Lake water, and isolated 13 microorganisms (bacteria and fungi). they reported that fungal have superior potential in adsorbing of heavy metals, so that A.niger and A.flavus absorbed about $97.88 \%$ of the sodium ions in the sea water while bacterial absorbed about $54.84 \%$ which reflected the absolute requirement of these organisms to sodium ions. Both bacterial and fungous absorbed High amounts of $\mathrm{Mg}$ ions. It shows that $\mathrm{Mg}^{+2}$ ions play an important role in many key metabolic reactions catalyzed by enzymes. Combination of bacterial isolates absorbed $90.13 \%$ of the dissolved $\mathrm{K}^{+}$ions in sea water, while fungal isolates absorbed lower quantities of $\mathrm{K}^{+}$ions. Combination of bacterial and fungal isolates (A.niger, A.flavus, M.roseus, M.kristinae and V.fluvials) is capable to absorb different metal ions as lead, copper, iron, cadmium and zinc in/on their cells [13].

Sabry et.al in 1996 studied the resistance patterns by a community of marine, aerobic heterotrophic and metal-resistant bacteria. The resistance patterns, expressed that, a great part of the isolates were sensitive to cadmium (99\%), zinc (84\%), nickel (40\%) and copper (22\%)[14].

Removal efficiency of anaerobic treatments on the leachate is shown in table 5 .

\section{Conclusions}

An innovative method was demonstrated to treat landfill leachate. In order to evaluate the biological treatability of the landfill leachate, the removal efficiency of COD, BOD and organic pollutants were investigated. Landfill leachate generated from Isfahan landfill site was of very poor quality, with high concentrations of numerous organic pollutants. The COD concentration was between 176000 and 127000 $\mathrm{mg} \mathrm{\textrm {L } ^ { - 1 }}$. The BOD concentration was between 49000 and $37000 \mathrm{mg} \mathrm{L}^{-1}$. The COD and BOD removal efficiency was about $93 \%$ and $92 \%$, respectively after treatment in the bio-reactor. The average effluent concentrations of COD and BOD were aboute 15000 and $5000 \mathrm{mg} \mathrm{L}^{-1}$, respectively. 


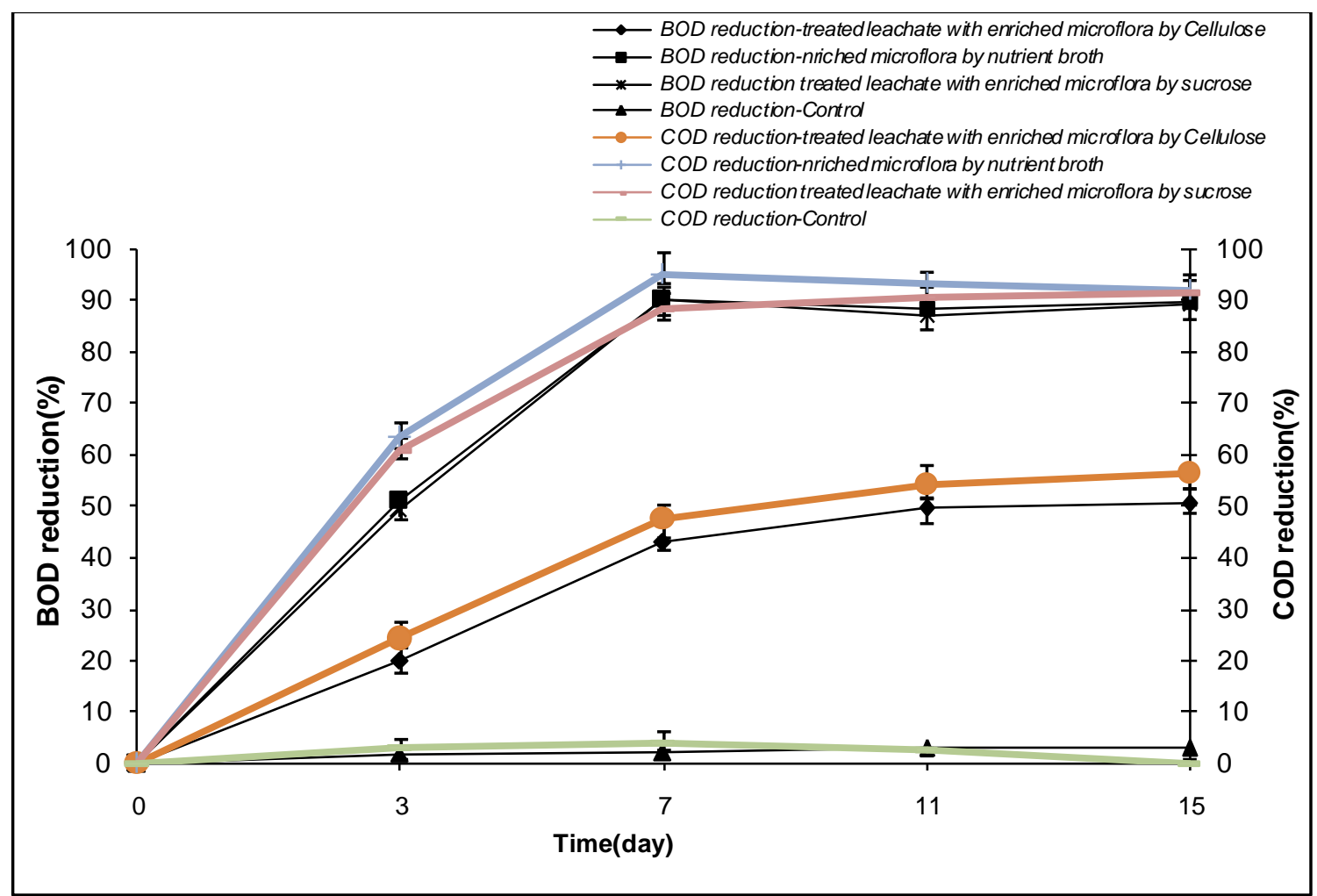

Figure 2. BOD and COD reduction of leachate after treatment with different enriched microflora in aerobic conditions within 15 days in shaker incubat or. Data are means of three replicates and error bars show standard deviation

Table 3. BOD, COD and TSS reduction of leachate aftertreatment with different enriched microflora in anaerobic conditions within 21 days

\begin{tabular}{|c|c|c|c|c|c|c|c|}
\hline & \multirow{2}{*}{$\begin{array}{c}\text { number of } \\
\text { samples }\end{array}$} & \multicolumn{2}{|c|}{ COD re duction (\%) } & \multicolumn{2}{|c|}{ BOD reduction (\%) } & \multicolumn{2}{|c|}{ TSS reduction (\%) } \\
\hline & & samples & average & samples & average & samples & ave rage \\
\hline \multirow{3}{*}{ Treated by sucrose } & S1 & 37.2 & \multirow{3}{*}{38.3} & 3.9 & \multirow{3}{*}{3.4} & 4.3 & \multirow{3}{*}{4.3} \\
\hline & $\mathrm{S} 2$ & 39.8 & & 2.8 & & 4.9 & \\
\hline & S3 & 38 & & 3.6 & & 3.7 & \\
\hline \multirow{3}{*}{$\begin{array}{l}\text { Treated by } \\
\text { nutrient broth }\end{array}$} & S1 & 5.9 & \multirow{3}{*}{5.3} & 32 & \multirow{3}{*}{31.2} & 2.1 & \multirow{3}{*}{2.3} \\
\hline & S2 & 4.8 & & 30.5 & & 2.4 & \\
\hline & S3 & 5.3 & & 31.2 & & 2.3 & \\
\hline \multirow{3}{*}{ Treated by cellulose } & S1 & 4.1 & \multirow{3}{*}{5.2} & 2.9 & \multirow{3}{*}{3.2} & 37.9 & \multirow{3}{*}{37.3} \\
\hline & S2 & 6.2 & & 3.8 & & 37.1 & \\
\hline & S3 & 5.3 & & 3 & & 37 & \\
\hline
\end{tabular}

Table 4. Removal efficiency of metals in the treated leachate with nutrient broth and sucrose in aerobic conditions. Dat a are means of three replicates

\begin{tabular}{|c|c|c|c|c|c|}
\hline \multirow[b]{2}{*}{ metals } & \multirow[b]{2}{*}{$\begin{array}{l}\text { before treatment } \\
\quad(\mathrm{mg} .1-1)\end{array}$} & \multicolumn{2}{|c|}{ treated leachate with nutrient broth } & \multicolumn{2}{|c|}{ treated leachate with sucrose } \\
\hline & & $\begin{array}{c}\text { removed } \\
\text { from leachate(mg.1-1) }\end{array}$ & Metal removal (\%) & $\begin{array}{c}\text { removed } \\
\text { from leachate(mg.l-1) }\end{array}$ & Metal removal(\%) \\
\hline $\mathbf{P b}$ & 2.71 & 2.21 & 81.54 & 2.25 & 83.02 \\
\hline Cd & 0.25 & 0.2 & 80 & 0.21 & 84 \\
\hline $\mathrm{Fe}$ & 43.5 & 41.34 & 95.03 & 39.4 & 90.57 \\
\hline $\mathbf{Z n}$ & 10 & 6.77 & 90.26 & 8.3 & 83 \\
\hline $\mathbf{C u}$ & 0.86 & 0.72 & 83.72 & 0.79 & 91.86 \\
\hline Mn & 6.8 & 6.76 & 99.41 & 6.76 & 99.41 \\
\hline $\mathbf{N a}$ & 2870 & 174 & 6.062 & 180 & 6.27 \\
\hline $\mathbf{K}$ & 3100 & 82 & 2.64 & 80 & 2.5 \\
\hline
\end{tabular}


Table 5. Removal efficiency of metals in the treated leachate with nutrient broth and sucrose in anaerobic conditions. Dat a are means of three replicates

\begin{tabular}{cc|cc|cc}
\cline { 2 - 5 } metals & \multicolumn{2}{c}{ treated leachate with nutrient broth } & \multicolumn{2}{c}{ treated leachate with sucrose } \\
\hline $\mathrm{Pb}$ & $\begin{array}{c}\text { before } \\
\text { treatment } \\
(\mathrm{mg} .1-1)\end{array}$ & $\begin{array}{c}\text { removed } \\
\text { from leachate(mg.l-1) }\end{array}$ & Metal removal (\%) & $\begin{array}{c}\text { removed } \\
\text { from leachate(mg.l-1) }\end{array}$ & Metal removal (\%) \\
$\mathrm{Cd}$ & 2.71 & 1.52 & 56.1 & 2.5 & 92.3 \\
$\mathrm{Fe}$ & 0.25 & 0.1 & 40.0 & 0.18 & 72.0 \\
$\mathrm{Zn}$ & 43.5 & 33.6 & 77.2 & 35.7 & 82.1 \\
$\mathrm{Cu}$ & 10 & 4.73 & 47.3 & 8.2 & 82.0 \\
$\mathrm{Mn}$ & 0.86 & 0.41 & 47.7 & 0.48 & 55.8 \\
$\mathrm{Na}$ & 6.8 & 5 & 73.5 & 6.52 & 95.9 \\
$\mathrm{~K}$ & 2870 & 189 & 6.6 & 145 & 5.1 \\
\hline
\end{tabular}

\section{ACKNOWLEDGMENTS}

We would like to thank The Isfahan University and Isfahan landfill management for providing the research facilities throughout the study.

\section{REFERENCES}

[1] Keenan JD, Steiner RL, Fungaroli AA. Landfill leachate treatment. Journal of WPCF. 1984; 56 (1): 27-33.

[2] Oman C, Hynning PA. Identification of organic compounds in municipal landfill leachates, Environmental Pollution. 1993; 80 (3): 265-271.

[3] Wintgens T, Gallenkemper M, Melin T. Occurrence and removal of endocrine disrupters in landfill leachate treatment plants. Water Science and Technology. 2003; 48 (3): 127-134.

[4] Zhang H, Choi HJ, Huang C. Treatment of landfill leachate by Fenton's reagent in a continuous stirred tank reactor. Journal of Hazardous Materials. 2006; 136 (3): 618-623.

[5] Chen S, Sun D, Chung JS. Simultaneous removal of COD and ammonium from landfill leachate using an anaerobic-aerobic moving-bed biofilm reactor system. Waste Manage. 2008;28(2):339-46.

[6] Atuanya EI, Purohit HJ, Chakrabarti T. Anaerobic and aerobic biodegradation of chlorophenols using UASB and ASG bio-reactors. World J. Microb. Biot. 2000; 16 (1):95-98.

[7] Shin HS, Han SK, Song YC, Lee CY. Performance of UASB reactor treating leachate from acidogenic fermenter in the two-phase anaerobic digestion of food waste. Water Research. 2001; 35(14): 3441-3447.

[8] Kennedy KJ, Lentz EM. Treatment of landfill leachate using sequencing batch and continuous flow upflow anaerobic sludge blanked reactors. Water Research. 2000; 34 (14): 3640-3656.
[9] Ahmet U, Fikret K. Biological nutrient removal from pretreated landfill leachate in a sequencing batch reactor. Journal of Environmental Management. 2004; 71 (1): 9-14.

[10] Banar M, Aysun O, Mine K. Characterization of the leachate in an urban landfill by physicochemical analysis and solid phase microextraction. GC/MS. Environ. Monitor.Assess. 2006; 121, (1-3): 437-457,

[11] Hamidi AA, Salina A, Nordin A, Faridah, Asaari AH, Shahrir Z. Colour removal from landfill leachate by coagulation and flocculation processes. $\mathrm{J}$ of Bioresource Technology. 2007; 98 (1): 218-220.

[12] Gotvajna T, Zgajnar A, Tǐsler b, Zagorc-Kon`cana J.. Comparison of different treatment strategies for industrial landfill leachate. Journal of Hazardous Materials. 2009; 15 (162):1446-1456.

[13] Meleigy MAEl, kasaby AMEl, Osman NH. Microorganisms as a Tool in Biotechnology of Sea Water Treatment. Journal of Basic and Applied Sciences. 2010; 4(6): 1083-1099.

[14] Sabry SA, Ghozlan HA Abou-Zeid DM. Metal tolerance and antibiotic resistance patterns of abacterial population isolated from sea water. Journal of Applied Mjcfobiology. 1997;82, 245-252

[15] Henze M, Harremoes P, Arvin E, Jansen JC. Wastewater Treatment, Biological and Chemical Processes. Springer-Verlag, Berlin, Germany, 1995.

[16] David C. Small Water Supplies. 1st ed, Trowbridge, Wiltshire. India Cromwell Press, 2004; 317

[17] Eaton AD, Clesceri LS., Rice E W., Greenberg AE., Franson M H. APHA-AWWA-WPCF. Standard Methods for the Examination of Water and Wastewater. 20th ed. American Public Health Association, Washington D.C, USA.1998

[18] Robinson HD. Development of methanogenic condition within landfill. Paper presented at Sardinia 1989: Second International Waste Management and Landfill Symposium, Porto Coute, Sardinia, Italy: 9-13, October 1989

[19] Accot Technologies Sdn. Bhd, (2008).Available from http://www.accot.biz. 